\title{
Ideology and Power in Political News Text: Appraisal in Critical Discourse Analysis
}

\author{
Setyo Prasiyanto Cahyono ${ }^{1}$ \\ setyo.cahyono@dsn.dinus.ac.id \\ Galuh Kirana Dwi A ${ }^{2}$ \\ galuh.uness@gmail.com \\ Sumarlam ${ }^{3}$ \\ sumarlam@staff.uns.ac.i \\ ${ }^{1}$ Universitas Dian Nuswantoro \\ ${ }^{2}$ Universitas Negeri Semarang \\ ${ }^{3}$ Universitas Sebelas Maret
}

\begin{abstract}
This study attempts to reveal the ideology and power expressed in the news text entitled "The burning scar: Inside the destruction of Asia's last rainforest". The data of this study were obtained from one of the most famous online Newspapers namely BBC. Whilst, in doing the critical analysis, systemic functional linguistics specifically the use of appraisal proposed by Martin and White (2005) was applied to find out the ideology as well as the power of the text. The findings show that there are three appraisal items found such as attitude, engagement, and graduation simultaneously. Affect is the most dominant appraisal found in the text. It represents the feelings of the people who live in Papua where their land has been destroyed by the world's largest exporter of palm oil from South Korea. Besides, they also criticize the Indonesian government which sold their land to the company without any notice to the tribe who live there. Then, engagement represents the tribe's voices where they have to move from their land. The last is graduation which represents the tribe's experience when they were kicked out from their land. Meanwhile, the ideology of the text is represented by the use of attitude consisting of affect, appreciation, and judgment. Furthermore, the power deals with the tribe's tenor such as contact, status dan affect.
\end{abstract}

Keywords: appraisal, ideology, political news, power, tribe

\section{INTRODUCTION}

Recently, a lot of researches on language refer to Systemic Functional Linguistics (SFL) pioneered by Halliday (1925-2018). Besides, Halliday (1985, p. 15) argues that language is related to the social context because humans can do many things and achieve varied goals by using language either in speaking, writing, listening, or reading. This relates to Martin and Rose (2003, p. 263) who state that every selection of the meaning of a definite text is motivated by a certain ideology. One of the approaches used in SFL is Critical Discourse Analysis (CDA), i.e. a study that is not just analyzing language usage but also seeing language as a social practice. Eriyanto $(2001$, p. 7) states that in CDA, there is a relationship between discourse and its situations, institutions and social structures.

News texts become the most favorite texts analyzed by using CDA. According to Eriyanto (2001), the ideology of a news can be observed through language choice as well as the grammatical structure used in news writing. This ideology is usually tailored to the target readers as news consumers. Ideological similarities between the news text as well its readers are considered important as part of the legitimacy of media domination towards the reading audience. Some studies which analyzed ideology in news texts are Ellyawati (2011), Mayasari (2013), Sumarlam (2015 $\&$ 2016), and Aili (2018). They used Fairclough's 
three interrelated analysis processes (i.e. the dimension of text description, the dimension of discourse practice by textual interpretation, and the dimension of socio-cultural by text explanation) in their studies.

Ideology in news texts can also be analyzed by using appraisal approach proposed by Martin and Rose (2003) or Martin and White (2005). Some researchers who used this approach are Warsono (2008), OTEÍZA S. (2009), Wati (2015), Marsakawati (2016), Parvin (2017), and Nurhadi (2017). Based on those reviews of previous literature, the researches will try to analyze not only the ideology of a news text, but we will also want to analyze the power of a news text entitled “The burning scar: Inside the destruction of Asia's last rainforest".

The analysis of this study focuses on theoretical approaches of SFL and CDA, mainly on Appraisal theory (White, 2003; Martin, 1997; Martin and White, 2005; Martin and Rose, 2003). Critical discourse analysis, herewith CDA, is a discourse research analysis which mainly focusing on study about improper social strength, superiority, and imbalance are assigned, duplicated, and rejected in text and talk in social and political context (Dijk,1998). CDA is one of approaches in discourse studies that offer different mode or perspective of theorizing, analyzing, and application through the whole field. This perspective can be in term of pragmatics, conversation analysis, narrative analysis, rhetoric, stylistics, sociolinguistics, ethnography, or media analysis (Arif, 2017). Moreover, Hart (2014, p. 2) argues that CDA is a particular form of discourse analysis which seeks to disclose the ideological and persuasive properties of text and talk. It means that CDA sees language as social phenomenon.

As cited in Santosa (2016), in SFL, Fowler introduces CDA and its concept which is taken from Halliday that language is a form of social and ideological action (Martin \& Rose, 2007: 314). CDA views the relation between language and ideology or language and power (Fairclough, 1995). Furthermore, SFL is a multi-perspectival model, designed to provide analysts with complementary lenses for interpreting language in use (Martin \& White, 2005: 7). One of the most complementarities is the notion of types of meanings/metafunctions including ideational (experiential) refers to what is happening, to the nature of the social action that is taking place: what it is that the participants are engaged in, in which language figures as some essential components; interpersonal meaning comprises who is taking part, to the nature of the participants, their statues and roles: what kinds of role relationships obtain, including permanent and temporary relationships of one kind or another, both the types of speech roles they are taking on the dialogue and the whole cluster of socially significant relationships in which they are involved; while textual meaning refers to what part language is playing, what it is that the participants are expecting language to do for them in the situation: the symbolic organization of the text, the status that it has, and its function in the context.

However, CDA may focus on particular metafunctions for example interpersonal metafunctions. Interpersonal function constitutes a grammar for evaluation. Evaluation is concerned with appraisal, the kind of attitude which are negotiated in a text, the strength of the feelings involved and they ways in which values are sourced and readers aligned (Martin and Rose, 2007, p. 25).

Appraisal system is used as the basic theory to analyze the data of this study. Martin and White (2005), Thompson (2014) and Martin and Rose (2007) argue that the goal of appraisal is to systematize the set of linguistic resources variety that the speakers and writers use to negotiate evaluations with their addresses and also to construct the solidarity around shared values. Martin and White (2005) classify appraisal into three subsystem as described in the figure below. 
Figure 1

Appraisal System (Source: Martin \& White, 2005)

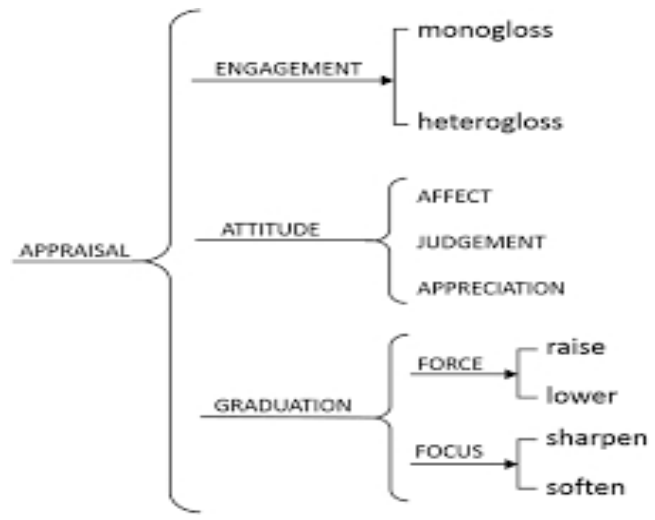

As it is shown in the figure above, it can be explained that attitude is concerned with our feelings, including emotional reactions, the judgment of behavior, and the evaluation of things. Engagement deals with sourcing attitudes and the play of voices around opinions in discourse. Meanwhile, graduation attends to grading phenomena whereby feelings are amplified and categories blurred (Martin and White, 2005, p. 35).

\section{METHODOLOGY}

This study employs a descriptive qualitative research design. The Source of the data includes political news text downloaded from an online English newspaper namely BBC. The aims of this study are to describe the ideology and power represented in political news texts entitled "The burning scar: Inside the destruction of Asia's last rainforests" written by Amindoni and Henschke from BBC Indonesia. The news was published in 12 November 2020 online at the bbc.com website. Meanwhile, the data of this study are in the form of words or phrases of the news text and are analyzed using Martin and White (2005) framework on the appraisal. The analysis starts by reading the news text, from the beginning to the last part, to recall the highlight contents. Since it is a text-based analysis, it means that the analysis is conducted on each text. Afterward, displaying the appraisal items data into table and appraisal categories. As the focus of this study is interpersonal metafunctions of the language used in political news text, it is based on Systemic Functional Linguistics (SFL) specifically on the level of discourse semantic of appraisal which leads to the understanding of ideology and power of the news text.

\section{RESULT AND DISCUSSION}

In this part, we present data and the analysis. The system of appraisal, covering attitude, engagement, and graduation, is presented in this section focusing on political news text of BBC online newspaper. The following table presents the findings of this study. 
Table 1

Appraisal Items of Political News Text

\begin{tabular}{|c|c|c|c|c|c|c|}
\hline \multirow{2}{*}{$\begin{array}{l}\text { Types of } \\
\text { Appraisal }\end{array}$} & \multirow{2}{*}{ Categories } & \multirow{2}{*}{$\begin{array}{l}\text { Sub- } \\
\text { categories }\end{array}$} & \multicolumn{2}{|c|}{$\Sigma$} & \multirow{2}{*}{$\begin{array}{l}\text { Sub- } \\
\text { total }\end{array}$} & \multirow{2}{*}{$\%$} \\
\hline & & & + & - & & \\
\hline \multirow[t]{13}{*}{ Attitude } & Affect & un/happiness & 63 & 7 & 70 & 34.83 \\
\hline & & in/security & 17 & 6 & 23 & 11.44 \\
\hline & & dis/satisfaction & 8 & 3 & 11 & 5.473 \\
\hline & \multicolumn{2}{|l|}{ Total of Affect } & & \multicolumn{3}{|c|}{104} \\
\hline & \multirow[t]{5}{*}{ Judgment } & Normality & 1 & & 1 & 0.498 \\
\hline & & Capacity & 17 & & 1 & 0.498 \\
\hline & & Tenacity & 4 & & 4 & 1.99 \\
\hline & & Veracity & 2 & & 2 & 0.995 \\
\hline & & Propriety & 16 & & 16 & 7.96 \\
\hline & \multicolumn{2}{|c|}{ Total of Judgment } & & & 24 & \\
\hline & \multirow[t]{2}{*}{ Appreciation } & Reaction & 17 & & 17 & 8.458 \\
\hline & & Composition & 13 & & 13 & 6.468 \\
\hline & \multicolumn{2}{|c|}{ Total of Appreciation } & & & 30 & \\
\hline \multirow[t]{7}{*}{ Engagement } & \multirow[t]{3}{*}{ Monoglos } & Disclaim & 4 & & 4 & 1.99 \\
\hline & & Proclaim & 7 & & 7 & 3.48 \\
\hline & & Entertain & 9 & & 9 & 4.48 \\
\hline & \multicolumn{2}{|c|}{ Total of Monogloss } & & & 20 & \\
\hline & \multirow[t]{2}{*}{ Heterogloss } & Contract & 2 & & 2 & 1 \\
\hline & & Expand & 4 & & 4 & 1.99 \\
\hline & \multicolumn{2}{|c|}{ Total of Heterogloss } & & & 6 & \\
\hline \multirow[t]{6}{*}{ Graduation } & Focus & & 9 & & 9 & 4.48 \\
\hline & \multicolumn{2}{|l|}{ Total of Focus } & & & 9 & \\
\hline & \multirow[t]{2}{*}{ Force } & Sharpen & 4 & 1 & 5 & 2.48 \\
\hline & & Soften & 3 & & 3 & 1.49 \\
\hline & \multicolumn{2}{|c|}{ Total of Force } & & & 8 & \\
\hline & \multicolumn{2}{|c|}{ Total } & & & 201 & \\
\hline
\end{tabular}

According to Table 1, the highest number of appraisal items is attitude with 158 occurrences found including affect with 104, judgment with 24 and appreciation with 30 .

Attitude

There are three attitude appraisal found in the data of news text. Those are affect, judgment

Table 2

Unhappiness: Antipathy Information

\begin{tabular}{llll}
\hline $\begin{array}{l}\text { Affect } \\
\text { Classification }\end{array}$ & Realization of Lexis & $\begin{array}{l}\text { Kinds of } \\
\text { feeling }\end{array}$ & Descriptive Information \\
\hline $\begin{array}{l}\text { Unhappiness: } \\
\text { Antipathy }\end{array}$ & $\begin{array}{l}\text { "This is our mini } \\
\text { market," he says, } \\
\text { smiling. "But unlike in } \\
\text { the city, }\end{array}$ & negative & $\begin{array}{l}\text { Negative feeling is felt by Petrus Kinggo, the } \\
\text { man who lives in Papua where his land is } \\
\text { bought by Korean Oil Company }\end{array}$ \\
\hline
\end{tabular}

and appreciation. Below is the description analysis of each type of attitude.

\section{Affect}

Following is the example of attitude affect found in the data. 
It can be seen in Table 2 that the underlined word is classified into group emotion as affect unhappiness: antipathy. It informs that Petrus Kinggo, the man who lives in Papua, feels unhappy with the situation in his regency. It happened because the biggest company in Korea has bought his land. He thinks that his land is just like a mini market because he and his people can freely find food and medicine.

Another example of attitude affect can be found in the following table.

Table 3

Satisfaction: Interest Information

\begin{tabular}{|c|c|c|c|}
\hline $\begin{array}{l}\text { Affect } \\
\text { Classification }\end{array}$ & Realization of Lexis & $\begin{array}{l}\text { Kinds of } \\
\text { feeling }\end{array}$ & Descriptive Information \\
\hline $\begin{array}{l}\text { Satisfaction: } \\
\text { Interest }\end{array}$ & $\begin{array}{l}\text { that the company was } \\
\text { involved in any human } \\
\text { rights violations }\end{array}$ & Positive & $\begin{array}{l}\text { Positive feeling is felt by Korindo that the } \\
\text { company involves in any human rights } \\
\text { violations. }\end{array}$ \\
\hline
\end{tabular}

Based on Table 3, it can be said that the underlined word can be segmented into group emotion as affect satisfaction: interest. It tells the readers that Kinggo believes there are human rights violations done by the Korean Oil Company to Papua tribe since they stole their land without any notice. The table below is another example showing affect classification.

Table 4

Unhappiness: Misery Information

\begin{tabular}{llll}
\hline $\begin{array}{l}\text { Affect } \\
\text { Classification }\end{array}$ & Realization of Lexis & $\begin{array}{l}\text { Kinds of } \\
\text { feeling }\end{array}$ & Descriptive Information \\
\hline $\begin{array}{l}\text { Unhappiness: } \\
\text { Misery }\end{array}$ & $\begin{array}{l}\text { "My brother would } \\
\text { never have sold his } \\
\text { pride or forest before," } \\
\text { she said, through tears. }\end{array}$ & negative & $\begin{array}{l}\text { Negative feeling is felt by Derek Ndiwaen } \\
\text { because he feels so stress over the land in } \\
\text { his tribe which was bought by Korean Oil } \\
\text { company. This tragedy leads him to death. }\end{array}$ \\
\hline
\end{tabular}

Based on Table 4, it can be seen that the datum shows negative affect of unhappiness: misery. It informs the readers of the newspaper that Derek Ndiwaen passed away because he felt so stress with the situation he experienced. In this case, he has made a deal with the representative of
Korean Oil company named Korindo to take some money for the payment of their land. Then, Derek becomes embroiled in conflict with other tribes over the land deals. As a result, it makes Derek frustrated and leads to his death. Table 5 is also an example of affect found in the data.

Table 5

Unhappiness: Disinclination Information

\begin{tabular}{llll}
\hline $\begin{array}{l}\text { Affect } \\
\text { Classification }\end{array}$ & Realization of Lexis & $\begin{array}{l}\text { Kinds of } \\
\text { feeling }\end{array}$ & Descriptive Information \\
\hline $\begin{array}{l}\text { Unhappiness: } \\
\text { disinclination }\end{array}$ & $\begin{array}{l}\text { He fears future generations } \\
\text { will have to "live off money" } \\
\text { rather than the forest. }\end{array}$ & negative & $\begin{array}{l}\text { Negative feeling is felt by Petrus } \\
\text { Kinggo that he fights to save his } \\
\text { land from Korean Oil company. }\end{array}$ \\
\hline
\end{tabular}

The Table 5 reveals negative affect of unhappiness: disinclination experienced by Petrus Kinggo. The realization of lexis above informs that
Mr. Kinggo is afraid of future generations will have to live off money rather than the forest. Besides that, he also blames the Indonesia 
government because they do not consult it with the villagers before giving the concession to Korindo rather than give the people pressure to accept the offer.

\section{Judgment}

Below are the analysis of attitude judgement found in the news text.

Table 6

Social Esteem: Capacity Information

\begin{tabular}{lllll}
\hline $\begin{array}{l}\text { Judgment } \\
\text { Classification }\end{array}$ & $\begin{array}{l}\text { Realization } \\
\text { of Lexis }\end{array}$ & $\begin{array}{l}\text { Kinds of } \\
\text { feeling }\end{array}$ & Descriptive Information \\
\hline $\begin{array}{l}\text { Social Esteem: } \\
\text { Capacity }\end{array}$ & $\begin{array}{l}\text { A Korean palm oil giant has been } \\
\text { buying up swathes of Asia's }\end{array}$ & Positive & $\begin{array}{l}\text { Positive judgment given by } \\
\text { writer of the article }\end{array}$ & \\
& largest remaining rainforests. & & & \\
\hline
\end{tabular}

According to Table 6, it can be seen that the underlined phrase is classified into positive judgment of capacity. It indicates that one of the biggest Korean palm oil has bought a huge land in
Papua to open new palm oil company. Another example of judgment can be illustrated in Table 7 of appraisal information below.

Table 7

Social Sanction: Propriety Information

\begin{tabular}{|c|c|c|c|}
\hline $\begin{array}{l}\text { Judgment } \\
\text { Classification }\end{array}$ & $\begin{array}{l}\text { Realization } \\
\text { of Lexis }\end{array}$ & $\begin{array}{l}\text { Kinds of } \\
\text { feeling }\end{array}$ & Descriptive Information \\
\hline $\begin{array}{l}\text { Social } \\
\text { sanction: } \\
\text { Propriety }\end{array}$ & $\begin{array}{l}\text { "After our forest has } \\
\text { been sold you } \\
\text { would think we } \\
\text { would be living a } \\
\text { good life". }\end{array}$ & Positive & $\begin{array}{l}\text { Positive judgment made by Elisabeth } \\
\text { that she and her family and other people } \\
\text { of her tribe whether they will have a } \\
\text { good life or not after their land has been } \\
\text { sold to Korean Company. }\end{array}$ \\
\hline
\end{tabular}

Table 7 describes that the underlined word "good" has a positive judgment. The datum informs that Elisabeth along with her tribe wants to live good life without any pressure from the government or the Palm Oil Company after their forest has been sold to Korea Oil Company. Table 8 also depicts the example of judgment found in the news text.

Table 8

Social Sanction: Propriety Information

\begin{tabular}{|c|c|c|c|}
\hline $\begin{array}{l}\text { Judgment } \\
\text { Classification }\end{array}$ & $\begin{array}{l}\text { Realization } \\
\text { of Lexis }\end{array}$ & $\begin{array}{l}\text { Kinds of } \\
\text { feeling }\end{array}$ & Descriptive Information \\
\hline $\begin{array}{l}\text { Social } \\
\text { sanction: } \\
\text { Propriety }\end{array}$ & $\begin{array}{l}\text { According to Elisabeth, } \\
\text { Korindo told the } \\
\text { community it would build } \\
\text { good roads and provide } \\
\text { clean water. }\end{array}$ & Positive & $\begin{array}{l}\text { Positive judgment given by the } \\
\text { Korean Palm Oil company that the } \\
\text { compay will build good roads and } \\
\text { clean water for the people. }\end{array}$ \\
\hline
\end{tabular}

The datum gives information that the judgment classification shows the group of social sanction of propriety. The lexis used in good as a sign which has a purpose to give confirmation that 
the Korean Palm Oil company will build good roads and clean water for the people of Papua after

Table 9

Social Esteem: Capacity Information they bought their land and build the company there.

\begin{tabular}{llll}
\hline $\begin{array}{l}\text { Judgment } \\
\text { Classification }\end{array}$ & $\begin{array}{l}\text { Realization } \\
\text { of Lexis }\end{array}$ & $\begin{array}{l}\text { Kinds } \\
\text { feeling }\end{array}$ & of \\
\hline $\begin{array}{l}\text { Social Esteem: } \\
\text { Capacity }\end{array}$ & $\begin{array}{l}\text { Those that can afford it use } \\
\text { generators but fuel costs } \\
\text { four times as much_as in } \\
\text { the capital Jakarta. }\end{array}$ & Positive & $\begin{array}{l}\text { Positive judgment given by Nakias } \\
\text { residents in the Ngguti district that } \\
\text { they consider for those who have } \\
\text { money can afford to use generator } \\
\text { even though it costs much money. }\end{array}$ \\
\hline
\end{tabular}

According to Table 9, it is seen that the judgment classification reveals the group of social esteem: capacity. It indicates that there is a positive evaluation made by Nakias residents in the Ngguti district of Papua towards those people who have money to use a generator for the electricity. It

Table 10

Appreciation: Valuation Information happened because their life did not change the way they hoped.

\section{Appreciation}

The tables provided below are the description of attitude appreciation found in the news text.

\begin{tabular}{llll}
\hline $\begin{array}{l}\text { Appreciation } \\
\text { Classification }\end{array}$ & $\begin{array}{l}\text { Realization } \\
\text { of Lexis }\end{array}$ & $\begin{array}{l}\text { Kinds of } \\
\text { feeling }\end{array}$ & Descriptive Information \\
\hline $\begin{array}{l}\text { Appreciation: } \\
\text { Valuation }\end{array}$ & $\begin{array}{l}\text { here food and } \\
\text { medicine are free. }\end{array}$ & Positive & $\begin{array}{l}\text { Positive appreciation produced by Petrus } \\
\text { Kinggo that he is really appreciate and grateful } \\
\text { that what he along with his tribe wants such as } \\
\text { food and medicine are free. }\end{array}$ \\
\hline
\end{tabular}

The above datum shows that appreciation classification is in the group of appreciation: valuation. The lexis used is an adjective free which aims to confirm that Petrus Kinggo gives positive appreciation about his land where he lives with his tribe in Papua. His land does not only give him and his tribe shelter but also free food and medicine for them. A similar example is also shown in Table 11.

Table 11

Appreciation: Composition: Balance Information

\begin{tabular}{|c|c|c|c|}
\hline $\begin{array}{l}\text { Appreciation } \\
\text { Classification }\end{array}$ & $\begin{array}{l}\text { Realization } \\
\text { of Lexis }\end{array}$ & $\begin{array}{l}\text { Kinds of } \\
\text { feeling }\end{array}$ & Descriptive Information \\
\hline $\begin{array}{l}\text { Appreciation: } \\
\text { Composition: } \\
\text { Balance }\end{array}$ & $\begin{array}{l}\text { The investigation found } \\
\text { evidence of fires on one of } \\
\text { Korindo's concessions over } \\
\text { a period of years in } \\
\text { patterns consistent with } \\
\text { deliberate use. }\end{array}$ & Positive & $\begin{array}{l}\text { Positive appreciation } \\
\text { produced by the writer of the } \\
\text { news text article. She } \\
\text { expresses her appreciation to } \\
\text { the Forensic Architecture } \\
\text { group because they have } \\
\text { found consistent patterns in } \\
\text { deliberating burning on the } \\
\text { land. }\end{array}$ \\
\hline
\end{tabular}


The table depicts the example of appreciation of composition: balance. It shows the writer's appreciation towards the Forensic Architecture group at Goldsmiths University in London and Greenpeace International which have published, in conjunction with the $\mathrm{BBC}$, some

Table 12

Appreciation: Valuation Information evidence about this destruction and land burning in Papua Indonesia. The result of the investigation shows deliberate consistent patterns. Below is another example showing appreciation which is found in the data.

\begin{tabular}{|c|c|c|c|}
\hline $\begin{array}{l}\text { Appreciation } \\
\text { Classification }\end{array}$ & $\begin{array}{l}\text { Realization } \\
\text { of Lexis }\end{array}$ & $\begin{array}{l}\text { Kinds of } \\
\text { feeling }\end{array}$ & Descriptive Information \\
\hline $\begin{array}{l}\text { Appreciation: } \\
\text { Valuation }\end{array}$ & $\begin{array}{l}\text { Sefnat Mahuze, a local } \\
\text { farmer, said he saw } \\
\text { Korindo employees } \\
\text { collecting leftover wood, } \\
\text { "the worthless stuff". }\end{array}$ & Negative & $\begin{array}{l}\text { Negative appreciation } \\
\text { produced by Sefnat Mahuze } \\
\text { a local farmer who gives his } \\
\text { negative appreciation to the } \\
\text { way how Korindo employees } \\
\text { collect leftover wood. }\end{array}$ \\
\hline
\end{tabular}

It can be seen in Table 12 that the types of appreciation are classified into valuation. It represents Sefnat Mahuze's negative appreciation towards what he sees when Korindo employees are collecting leftover wood in the land that has been burned by the Korea Palm Oil company. He thinks that this action is impractical because it is their land and they should have more than this.

\section{Engagement}

The type of engagement mostly found in the data is monogloss. It is classified into entertain and attribute. Those can be seen in the following examples which are provided in some tables.

Table 13

Engagement: Entertain Information

\begin{tabular}{llll}
\hline $\begin{array}{l}\text { Engagement } \\
\text { Classification }\end{array}$ & $\begin{array}{l}\text { Realization } \\
\text { of Lexis }\end{array}$ & $\begin{array}{l}\text { Kinds of } \\
\text { feeling }\end{array}$ & Descriptive Information \\
\hline Engagement: & $\begin{array}{l}\text { This suggests that the } \\
\text { Entertain }\end{array}$ & Positive & $\begin{array}{l}\text { Positive engagement made by the } \\
\text { fires were set }\end{array}$ \\
& $\begin{array}{l}\text { intentionally Samaneh } \\
\text { Moafi said. }\end{array}$ & & $\begin{array}{l}\text { Forensic Architecture that they found the } \\
\text { pattern, the direction and the speed with } \\
\text { which fire had moved matched perfectly. }\end{array}$ \\
\hline
\end{tabular}

The Table 13 gives information that the lexis suggests includes in the group of engagement: entertain. It shows a suggestion made by the Forensic Architecture that they found a pattern through their satellite imagery which is used to study the pattern of land clearing inside a Korindo concession named PT. Dongin Prabhawa. Surprisingly, the satellite gives them a picture of some lands covered by fire in some districts of Papua. Engagement of entertain is also found in the example provided in Table 14.

Table 14

Engagement: Entertain Information 


\begin{tabular}{|c|c|c|c|}
\hline $\begin{array}{l}\text { Engagement } \\
\text { Classification }\end{array}$ & $\begin{array}{l}\text { Realization } \\
\text { of Lexis }\end{array}$ & $\begin{array}{l}\text { Kinds of } \\
\text { feeling }\end{array}$ & Descriptive Information \\
\hline $\begin{array}{l}\text { Engagement: } \\
\text { Entertain }\end{array}$ & $\begin{array}{l}\text { "They piled up long rows, } \\
\text { maybe 100-200 metres long, } \\
\text { and then they poured } \\
\text { petrol over it and then lit } \\
\text { them," he said. }\end{array}$ & Positive & $\begin{array}{l}\text { Positive engagement made by Sefnat } \\
\text { Mahuze that he considers the palm } \\
\text { oil company has piled up long rows } \\
\text { and poured petrol over it. }\end{array}$ \\
\hline
\end{tabular}

As seen in the table above, the lexis maybe belongs to the engagement of entertainment. It describes the possible range of distance of petrol they poured along the rows they want to burn. It seems that the fire in Papua had been set intentionally by the company to clear the land and build the company. Table 15 is another finding of engagement found in the data.

Table 15

Engagement: Proclaim Information

\begin{tabular}{llll}
\hline $\begin{array}{l}\text { Engagement } \\
\text { Classification }\end{array}$ & $\begin{array}{l}\text { Realization } \\
\text { of Lexis }\end{array}$ & $\begin{array}{l}\text { Kinds of } \\
\text { feeling }\end{array}$ & Descriptive Information \\
\hline $\begin{array}{l}\text { Engagement: } \\
\text { proclaim }\end{array}$ & $\begin{array}{l}\text { "There was no doubt that } \\
\text { Korindo had been in } \\
\text { violation of our rules. }\end{array}$ & Positive & $\begin{array}{l}\text { Positive engagement made by Kim } \\
\text { Carstensen, the FSC's executive } \\
\text { director that she strongly sure Korindo } \\
\text { breaks the rules. }\end{array}$ \\
\hline
\end{tabular}

The example shows that the lexis no doubt is segmented into engagement proclaim. This lexis is produced by a woman who works for the Forest Stewardship Council (FSC). She told the BBC at the group's headquarters in Germany. She suspected that Korindo had made a mistake and broken the FSC's rules because they had cleared the land without any notice and neglected forest conservation. They also did not respect the community rights and livelihoods.

\section{Graduation}

There are two types of graduation namely force and focus. Meanwhile, the type of graduation mostly occurred in the data is force. It can be seen clearly in the table below.

Table 16

Graduation: Force: Intensification Information

\begin{tabular}{|c|c|c|c|}
\hline $\begin{array}{l}\text { Graduation } \\
\text { Classification }\end{array}$ & $\begin{array}{l}\text { Realization } \\
\text { of Lexis }\end{array}$ & $\begin{array}{l}\text { Kinds of } \\
\text { feeling }\end{array}$ & $\begin{array}{l}\text { Descriptive } \\
\text { Information }\end{array}$ \\
\hline $\begin{array}{l}\text { Graduation: } \\
\text { Force: } \\
\text { Intensification }\end{array}$ & $\begin{array}{l}\text { That was very clear Kim } \\
\text { Carstensen, the FSC's executive } \\
\text { director, told the BBC at the } \\
\text { group's headquarters in } \\
\text { Germany. }\end{array}$ & Positive & $\begin{array}{l}\text { Positive feeling } \\
\text { experienced by Kim } \\
\text { Carstensen that } \\
\text { Korindo made violation } \\
\text { towards the FSC's rules. }\end{array}$ \\
\hline
\end{tabular}

Based on the table, the underlined word or lexis very belongs to graduation: force: intensification. It indicates that there is a degree of intensity made by the speaker. In this case, Kim Carstensen gives information that Korindo has

Table 17

Graduation: Force: Intensification Information made a violation to the FSC's rules. In her statement, Kim's statement "that was very clear" has a meaning that there is a strong statement made by Kim if Korindo makes mistakes. Below is also an example of graduation found in the data. 


\begin{tabular}{|c|c|c|c|}
\hline $\begin{array}{l}\text { Graduation } \\
\text { Classification }\end{array}$ & $\begin{array}{l}\text { Realization } \\
\text { of Lexis }\end{array}$ & $\begin{array}{ll}\text { Kinds of } \\
\text { feeling }\end{array}$ & Descriptive Information \\
\hline $\begin{array}{l}\text { Graduation: } \\
\text { Force: } \\
\text { Intensification }\end{array}$ & $\begin{array}{l}\text { But in the cases that we were } \\
\text { looking at there was a very clear } \\
\text { directionality," she said. }\end{array}$ & Positive & $\begin{array}{l}\text { Positive feeling reflected by } \\
\text { Samaneh Moafi that the pattern of } \\
\text { fire is very clear set up. }\end{array}$ \\
\hline
\end{tabular}

As seen in Table 17, the lexis very is classified into graduation: force: intensification. It gives information that Korindo has set the fire intentionally in Papua. According to Samaneh Moafi, the fires were set from outside the

Table 1

Graduation: Force: Intensification Information

\begin{tabular}{llll}
\hline $\begin{array}{l}\text { Graduation } \\
\text { Classification }\end{array}$ & $\begin{array}{l}\text { Realization } \\
\text { of Lexis }\end{array}$ & $\begin{array}{l}\text { Kinds of } \\
\text { feeling }\end{array}$ & Descriptive Information \\
\hline $\begin{array}{l}\text { Graduation: } \\
\text { Force: }\end{array}$ & $\begin{array}{l}\text { where are our ancestors' spirits } \\
\text { Intensification }\end{array}$ & Negative & $\begin{array}{l}\text { Negative feeling felt by the tribe } \\
\text { completely destroyed. And it }\end{array}$ \\
& happened under my watch." & & $\begin{array}{l}\text { who lived in Papua because their } \\
\text { land has been destroyed. }\end{array}$ \\
\hline
\end{tabular}

According to the table, the realization of lexis completely is realized in graduation: force: intensification. It indicates that the land where the people live in Papua has gone. They do not have any space to live. Furthermore, the land where their ancestors were buried has now been destroyed.

\section{Ideology and Power}

The realization of Ideology can be done by using the analysis of attitude which includes analysis of affect, judgment, and appreciation. Whereas, Power can be realized through the analysis of engagement and graduation. As we can see from Table 1, the ideology of the news text is realized in 158 occurrences of 104 affect, 24 judgment, and 30 appreciation. Affect, which is referred to as an emotion, is dominated by positive feelings with 63 happiness, 17 security, and 8 satisfaction. These positive affects tend to show the feelings of the Papua people who love their land very much because it actually can freely provide them with anything they need in life. From the company's point of view, the positive affect realizes their security in having protection from the state security forces. Whereas, the negative concession, or due to weather conditions, they would have moved with a different directionality. In fact, it is very clear that the pattern of fire is made directionally. Table 18 is also an example of graduation found in the data. affect lexis which includes 7 lexis of unhappiness, 6 lexis of insecurity, and 3 lexis of dissatisfaction realize Papua people's sadness of being deceived by the company and the government and the company's denial of being accused of breaking the human rights.

There is 24 judgment lexis found in the news text. The judgment, which is traditionally referred to as ethics, generally realizes Papua people's disappointment because the company breaks their promises to give some facilities to them. In addition, there is 30 lexis of appreciation found in the news text. The appreciation, which is referred to as aesthetics, mostly realizes Papua people's gratitude for having a very useful live needs forest.

On the other hand, the realization of Power can be done by using the analysis of engagement and graduation. For engagement, there are 20 lexis of monogloss and 6 lexis of heterogloss. Whereas for graduation, there are 9 lexis of focus and 8 lexis of force. Generally, the engagement is used to realize that there are a lot of statements, opinions, and arguments, given by both Papua people as well as the company. It means that both parties have the same position in giving their evaluation to the news writers. As a matter of fact, Papua 
people seem to have a lower position compared to the company because they feel that they lost not only their land but also their dignity.

\section{CONCLUSION}

It can be concluded that the ideology represented in the news texts realizes Papua people's feeling of being deceived by the Korean biggest Palm Oil Company. While the Power realizes that Papua people have lower status against the company since they do not have any power to get their land back to their hands.

\section{REFERENCES}

Amindoni, A., \& Henschke, R. (2020). The burning scar: Inside the destruction of Asia's last rainforests.

https://www.bbc.com/news/world-asia$\underline{54798452}$.

Aili, I. (2018). Virus wannacry dalam teks berita: Analisis wacana kritis atas laman kemkominfo, Kompas.Com, dan Jawapos.Com. Paradigma Jurnal Kajian Budaya, 8(2), 137-154.

Arif, M. (2017). Appraisal and critical discourse analysis in Shark' Song Lyric. CLLT., 503508.

Dijk, T.V. (1998). Critical Discourse Analysis.

Handbook of Discourse Analysis. University of Amsterdam.

Ellyawati, H.C. (2011). Analisis wacana kritis teks berita kasus terbongkarnya perlakuan istimewa terhadap terpidana suap Arthalyta Suryani pada media online. The Messenger, 3(1).

Eriyanto. (2001). Analisis Wacana. LkiS Malang.

Fairclough, N. (1995). Language and Power. Longman

Halliday, M.A.K., \& Hasan, R. (1985). Language, Context, and Text: Aspects of Language in a
Social-semiotic Perspective. Brown Prior Anderson Pty Ltd.

Hart, C. (2014). Discourse, Grammar and Idelogy. Bloomsbury.

Martin, J.R., \& Rose, D. (2003). Working with Discourse: Meaning Beyond the Clause. Continuum.

White, P.R.R, \& Martin, J.R. (2005). The Language of Evaluation: Appraisal in English. Palgrave Macmillan.

Mayasari et al. (2013). Analisis wacana kritis pemberitaan "Saweran untuk Gedung KPK" di harian umum Media Indonesia. Jurnal Linguistik Terapan.

Marsakawati, N.P.E. (2016). Appraisal in the Jakarta Post article entitled "Ending Poverty, Ending Violence Against Women." Parole: Journal of Linguistics and Education, 6 (1), 1-7.

Nurhadi, K. (2017). The appraisal analysis of national exam issues: A discourse analysis. ELT Perspective 5 (1),.

Oteíza S., T. (2009). Evaluative patterns in the official discourse of human rights in Chile: Giving value to the past and building historical memories in society. D.E.L.T.A., 25, 609-640.

Parvin, L.m. (2017). CDA undertaken through SFL: Employment of appraisal in critical discourse analysis of the news. International Journal of Linguistics and Literature (IJLL), 6(4), 23-30.

Santosa, R. (2016). Critical Discourse Analysis (CDA): Systemic Functional Linguistics (SFL). Prosiding PRASASTI, 46-57.

Sumarlam. (2015). Analisis wacana kritis teks berita "Mencari Solusi Konflik Keraton Surakarta". Proceeding International Conference on Linguistics 2015: Program Studi Ilmu-Ilmu Sastra S-3, Program Pascasarjana, Fakultas Ilmu Budaya, Universitas Padjadjaran, Bandung.

Sumarlam. (2016). Representasi kekuasaan melalui sabda raja pada teks berita mengenai konflik 
internal keraton Yogyakarta (sebuah analisis wacana kritis). Proceeding Seminar International PRASASTI III: Program Studi Linguistik, Pascasarjana UNS dan Balai Bahasa Provinsi Jawa Tengah, Surakarta, 2 3 Agustus 2016.

Thompson, G. (2014). Introducing Functional Grammar. JW Arrowsmith Ltd.
Warsono. (2008). A critical discourse analysis to unmask the ideological stance behind "Alqaeda in the Asia Pacific: Origin, capability, and threat." Humaniora, 20(2), 191-199.

Wati, E.P., Tallapessy, A., \& Diana, S. (2015). Bias and power: Appraisal in media discourse keberpihakan dan kuasa: Penaksiran dalam wacana media. Publika budaya, 1(3), 65-71. 